\title{
An Internet Based Distribution Strategy of Luxury Products and Services Grounded on Qualitative Web Discourse Analysis
}

\author{
Alexandra Broillet \\ Haute Ecole de Gestion \\ Genève (HEG Genève) \\ alexandra.broillet@hesge.ch
}

\author{
Magali Dubosson \\ Haute Ecole de Gestion de \\ Genève (HEG Genève) \\ magali.dubosson@hesge.ch
}

\author{
Jean-Philippe Trabichet \\ Haute Ecole de Gestion de \\ Genève (HEG Genève) \\ jean- \\ philippe.trabichet@,hesge.ch
}

\begin{abstract}
Nowadays Internet users' behavior when using Web 2.0 technologies is mostly ignored in marketing research, and therefore is, in particular, absent in the luxury internet strategy literature.

This paper contributes to answering the following research question: Can Netnography [1-4] be used as a research method and how can it be used efficiently in order to design internet strategy such as online communication and distribution? Different blogs dedicated to luxury products were analyzed in order to test this research method in the luxury sector.

What Internet users interested in luxury goods and services were saying and writing in different blogs dedicated to luxury products was analyzed with the netnography methodology. Postings discussing luxury watch brands, luxury cars, luxury travel and art objects were analyzed through the frequency of particular terms in order to give an idea of the most stated opinions and the perception of the products and services.

Results showed that Web 2.0 can no longer be ignored and should be fully integrated in the communication and distribution strategy, even in the case of luxury products and services.

Keywords: Netnography - Luxury e-commerce consumer attitude - strategy - Web 2.0
\end{abstract}

\section{Introduction}

There is a significant contrast between the need for tools for virtual marketing research and the luxury ecommerce reality. Nyeck and Roux [5] were the first to do academic research in luxury e-commerce. They discussed the different opportunities and weaknesses of luxury ecommerce. Data was collected through interviewing of professionals. Dall'Olmo Riley and Lacroix [6] designed a questionnaire evaluating the perception of virtual consumers and made a content analysis of 54 luxury brand sites. Lee [7], and Wang and al. [8], interviewed consumers about their attitude toward virtual stores and used a questionnaire to collect field data. Metha and
Sivada [9], Bergadaà and Hebali [10], Weltevreden [11] used questionnaires that were sent via e-mail. Kozinets [1-4] designed, tested and discussed a new methodology specifically conceived to observe consumer behavior in the Net environment, named Netnography.

At the time being, companies are still mostly selling their goods and delivering their services through their networks of independent wholesalers. Some diversified luxury goods groups, like LVMH, have their own physical and virtual distribution network. Taking into account the economic and commercial issues arising from the existing physical distribution of their goods, the ecommerce issues and challenges would be viewed very differently in the e-commerce strategies of the various luxury goods companies. To get a better idea of the ecommerce strategies of luxury goods companies, we interviewed 12 luxury experts. Each of them has a different idea of what has to be done and of the needs and expectations of the luxury consumer. Some experts think that the status quo is the best solution with the Internet as an online catalog and the brick-and-mortar luxury retailer network fulfilling the distribution and servicing support role. Therefore, to get a better idea of what should be done, we decided to use the Netnography methodology. It had never been used as a research tool for luxury ecommerce issues before.

\section{Netnography as a research tool}

Nethnography [1-4] uses textual outputs of different blog discussions in order to contribute to our internetrelated field research. It is a qualitative research method of investigation of consumer behavior within cybercultures and virtual communities. A virtual community [12] is understood as "... a social group that has a "real" existence for the participants, and thus has consequential effects on many aspects of behavior, including consumer behavior". [2]

This kind of research permits the observation of Internet communities without participating actively and in 
an anonymous way. Observational research in internet contexts has already been discussed in the literature $[6 ; 9$ 13]. Netnography was inspired by techniques of cultural anthropology [1;3]. Participants of virtual communities are living a sort of real life in a kind of "Blogosphere" [14] and do not simply exchange information about luxury goods and services.

Interactions and level of involvement were observed; web 2.0 users were sorted according to four identified categories [4]:

- Tourists (lack of strong social ties or of deep interest - often post casual questions)

- Minglers (strong social ties but minimal interest in the activity)

- Devotees (strong consumption interest but few attachments to the online group)

- Insiders (strong ties and tend to be long-standing and frequently referenced members).

Devotees and insiders should represent the most important data sources [2]. They represent the category of Netsurfers who are the most active participants in luxury blogs.

Research ethics [2] have been discussed in the literature; it is not clear whether forums or blogs are to be considered as private or public sites. They might be considered as public because of the posting a message to a technical base that is open or accessible to anybody, whether they belong to a certain community or not.

\section{Analyzing Web 2.0 content as a marketing research tool}

Bloggers' behavior can be representative of the whole Web 2.0 generation. These users can be considered as the most advanced Internet users and they are certainly fond of up-to-date technology.

In contrast to many luxury goods practitioners, we assumed that bloggers are not necessarily young and rather low-income people that can be neglected by luxury companies as a valuable marketing target. A study revealed that $76 \%$ of Americans earning more than 150.000 dollars per year are regularly spending time reading blogs [15]. So can the luxury industry still continue to ignore online communication and distribution, as well as all the Web applications that go with the Internet world?

O'Reilly [16] was the first to define the Web 2.0 as an interactive platform, offering dynamic solutions that fasten to $\mathrm{B} 2 \mathrm{C}$ communication. Later on, the literature is showing two axes, the original one, which is based on the social networking aspects and the other one which is focusing on the development of the RIA (rich interface application).

We prefer the social networking definition [16] because it focuses on the participation of people instead of putting forward the technical aspects enabling participation. WEB 2.0 offers opportunities to companies to build better relationships with their customers [6] and it may engender a higher level of customer loyalty to the brand. That would be a new approach for luxury companies as they are presently relying on intermediaries and, consequently, they are rarely dealing directly with their customers.

Based on marketers' interviews, Parise and Guinan [17] suggested four principles to guide marketing professionals in their actions:

1. Let your customers contribute to your marketing content. The luxury sector is very much concerned about controlling brand images. Professionals do not even think about letting customers contributing freely to marketing content.

2. Focus on community, not just content. Communities do not like the feeling that they are only serving as a way of collecting knowledge for the company's sake. Luxury companies might encourage Netsurfers to talk about specific subjects. In order to generate traffic and comments, community members have to be conscious of incentives such as network opportunities among themselves or peer recognition.

3. The Authenticity of the Message is better when coming from Other Customers. But marketing managers recognized that this type of user-generated content represented a risk to the brand because consumers were shaping how a product or a service was being perceived in the marketplace [17]. Existing communities are already discussing via blogs, such as the one for watch afficionados, www.thepurists.com.

\section{Experiment with Digital Media. New} technical opportunities may represent new opportunities for luxury companies, like "the live chat" on the www.lussori.com website. We tested this service on the US e-commerce site for luxury watches. After having typed the first question, we had to wait 2 minutes to get the following message, "All operators are currently assisting others. Thanks for your patience. An operator will be with you shortly." After an additional minute, we received an invitation to 
start a conversation. We have received replies to simple questions concerning website contents after 1 minute, in average. Replies to specific questions such as international shipping rates and delivery policies to specific destinations came after more than 4 minutes. Moreover, the answers were vague and not fully satisfying especially from the point of view of a luxury consumer. For those who are frequently using online chats, waiting a few minutes is far too long and is not acceptable considering the high standards prevailing in the luxury sector.

The main hindrance to selling products through the Internet is the lack of face-to-face human contact. Different studies have shown that about $2 \%$ of Internet users buy online. But, $40 \%$ of them would do so, if they had the opportunity to get in touch with an expert. So what are the solutions for "rehumanizing" the online experience?

Presently, several solutions are offered, such as:

- Intelligent robots, for instance a virtual person that can be activated to become an helper or a guide for the internet user, (like a virtual woman called Mona which is assisting the user on a French media website, www.france5.fr)

- Co-browsing and, or chat, that can assist the user via a human assistant (like http://www.crm.webhelp.fr/fiches/chat cobrowsing.html)

- Skype connections, which enable the user to contact vocally a help desk without leaving his computer (like http://www.getax.ch/pm/Contact.html )

- Telephone service via a website address.

Might intelligent robots be a solution for an online service? We believe that an intelligent robot has to be used in connection with a human who is able to answer specific questions. Otherwise a company has to assume the risk of losing a consumer and of damaging its brand image.

Web 2.0 allows an interface customization of an ecommerce platform. The luxury client may choose himself his own visual representation of the company. This concept is already well known by MyGoogle, Mymarque, or you may see it on my Tag Heuer or on the French labor party site (www.partisocialiste.fr ).

\section{Application: Luxury e-commerce context}

Some luxury products can be bought on the Internet, either through a brand operated website (for instance, www.dior.com, $\quad$ www.louisvuitton.com or www.121time.com) or through an e-commerce portal such as www.eluxury.com or www.watchestore.net.

Luxury e-commerce has only recently been started by the official luxury brands, like Dior or LVMH; luxury watch brands are still absent. Some wholesalers, like Bucherer or Lussori, started with an official website in the United Sates.

The luxury industry feels considerable apprehension about the Internet, especially when the opportunity of selling products on the web is being considered, since the Internet is often associated with price discounts. It still underestimates the prospect of targeting internet users. Is it right or wrong? Is it missing customers as it is not delivering right to them through the web? Are Internet users wealthy enough and enthusiastic enough to buy expensive watches over the Internet? Would they be more willing to buy them because they can get what they prefer without leaving their computer screen? On the one hand, we can observe the benefit of buying on the Internet.

On the other hand, the literature discusses the different types of risks related to e-commerce. Lee [7] observed that virtual shops increase the financial risk for the consumer; especially if he/she has concerns about security aspects when paying with a credit card, and about the fact that payment must be made in advance and it is necessary to wait for the delivery. This risk might be emphasized when ordering a luxury product or service. Nevertheless, this type of risk was also heavily discussed at the time that online banking services were launched. We all know that banking services are safe and are part of our everyday life, so why should one have such apprehensions when dealing with luxury products?

The consumer is even more worried as he/she cannot rely on a brand name as a guarantee in case something wrong happens as the luxury products are not sold by authorized well known companies, i.e. neither distributors nor manufacturers. Moreover, in the case of an international sale there may be uncertainties about the final real price because of the various legal aspects (such as additional charges due to customs and duties) and exchange rates.

The consumer also would have to take on the risk that the product purchased online does not really meet his/her expectations as he/she cannot see, touch or feel the product before buying on the Internet if he/she does not go to a "physical dealer" [6-7] beforehand. In this case, brick-and-mortar points of sale could complement the online solution as a way of mitigating this risk. Furthermore, by integrating traditional distributors and by 
rewarding them for this role, it might avoid channel conflict.

Lee [6] has also shown that an online purchase may also include a risk of a wrong perception of product functionalities. In order to mitigating this kind of risk, Chaumet, a luxury jewel brand, is offering a consulting service via mail or over the phone (http://www.chaumet.com/default.html). The consumer just needs to click on "contact us" and answer a few questions, such as phone number and the best time to call back. Chaumet will reach the consumer immediately or within 1- to 3- minute time lag when immediate service is desired.

\section{Methodology}

For a better understanding of the behavior and the attitudes of Internet users interested in luxury goods and services, we analyzed what they were saying and writing on different blogs dedicated to luxury products. The analyses of their postings gave us an idea of their most often stated opinions and their perception of luxury watch brands, luxury cars, luxury travel and art objects. Netsurfer discourses had to be about the luxury object or service, otherwise we excluded it from our sample, as we did it with luxury boat Blogs. It was interesting that Netsurfers were talking about everything, except about luxury boats.

In order to collect our data, we concentrated on two different types of Web 2.0 applications:

1) "Chats" that treated specifically the subject of luxury watches, cars, travel and art object arts, like those for watches (Watch Talk Forum, l'horlogeriesuisse.com, forums.timezone.com, watchparadise.com/blog, forums.watchuseek.com or the proper section about watches in Small World).

2) Selling platforms, which were existing only for luxury watches and travel, including interactive blogs (like portero.com, thewatchery.com, Vialuxe, traveler.fivestaralliance.com).

The selection of different Web 2.0 platforms was done through the "Google blog search" tool. After having visited many of them, we selected 23 blogs that fit our selection criteria. Single opinion providers or coordination by a few bloggers on Web 2.0 platforms, were excluded from our database. After an observation period of 4 months, we finally collected 470 pages and

43.000 words dealing with luxury watch brands

- $\quad 8.546$ words discussing about luxury cars

- $\quad 14.695$ words commenting on luxury travel

- 4.803 words arguing about luxury art objects.
We were only analyzing the parts of the different discourses that were treating luxury goods and services. Content analyses were done through the application of specific software which was developed by us. It counted the frequency of the words. The use of software excluded the need for different members of our research project to read the discourses several time at this stage. [4] The highest frequencies represent the words that were used most often in the selected blogs. Then, researchers categorized these words into categories. Those categories went through a repeated perception control process by all research members of this project. We have compared our results and kept only the significant ones. Special attention was paid to Netsurfer discourses about distribution.

\section{Discussion of results}

The category which is including the highest frequencies stands for the words which are describing the opinion of a person and the way in which the blogger conceives the world of luxury goods and services. There is a difference between the communication messages sent by the luxury goods and services companies and the point of view of the bloggers.

The watch, the car, the travel or art object: personal opinion and future visions (such as "However, the injection of more and more technology into cars is taking that enjoyment away... No, this feature creep is not for me." "Driving in Boston, I can tell you that whether a car has a blind spot warning system or not makes seemingly no difference at all!..." "Spas and spa-goers will learn to recognize and appreciate the really gifted therapists..." "Relaxing at a spa is good for your body, mind, spirit...and conception..." "I'd like to have something younger than a Rolex...")

The watch, the car, a travel or art object, considered as property and the experience of having chosen this product or service, bloggers use them, used them or would like to use them (such as "After many opportunities (BMW 530i, 745i, 650i, X5, and our recent 535i) to play with it, I'm comfortable with iDrive..." "Half Moon on Jamaica's Montego Bay..." "Today I'm going to try to get rid of conceptual art..." "Which makes me happy to part way with my flawless "Chopard Ice Cube with diamonds" all over paved diamonds in $18 \mathrm{~K}$ white gold, a brilliant quartz time keeper which just appraised for \$ 19,210? I have the original box, certificates and 3 additional leather wrist bands... ").

Emotional discourse about the watch and the car itself (such as "The big C pillar on many vehicles turns me off..." "la Maybach 62 S Landaulet est officielle et assez attirante ma foi par rapport à la limousine 
'standard", "the greatest luxury in life, is time.... Savor every second" "I really think it's a great idea also some of my designer colleges will be enthusiastic. I'll love to design the front face for a watch "the time to have time for people who have no time... You guys are the best and I love the watch...")

Experts comment on luxury watch brands, cars, travel and art objects (such as "After reading, I thought of myself being close-minded and stubborn toward art. I felt like I needed to at least try to understand art..." "When you've vacationed in Patagonia, the BVI, and the Greek Islands, and cruised the Nile and Yangtze rivers, what's next?" "I would imagine that a tire that loses pressure so rapidly (within 50 yards!) would also jeopardize vehicle handling. Run-flats offer a distinct advantage when it comes to maintaining control.")

Announcement of novelties, innovations and new models, it's like a new form of "buzz-marketing". Consumers discuss their experiences of luxury goods and services in their own decision process of buying (such as "En effet, il ne s'agit pas là d'une simple Ferrari F40 noire en photo du jour ou hurlante sur le banc d'essai..." "Mais ce nouveau concept car Audi, après celui préfigurant la future petite Al présenté récemment, annonce le futur crossover de la marque aux anneaux... " "Apple23's emphasis on the beauty of art is also similar and I plan on emphasizing the subject of beauty as well..." "Blanpainc 50 fathoms, I love the latest Breitling Super Ocean (probably the most beautiful breitling in 20 years), or even the eternal seamaster...")

Other categories are including price (". . . noticed your query!!! It's around 250 pp I believe..."), the ages ("I collect vintage Rolex since 20 years and very well known by the community...") of watch models, cars, travel, colors, material, technical information and design. The highest frequencies for technical information were found in luxury watch and car blogs. Mainly discourses were relational, functional or technical.

The distribution category encompassed different discussions about physical and virtual channels ("Experienced any hotel perk that can top this list?!..." "As you can see in the ad's copy, Portero has been getting great reviews from respected publications like The Wall Street Journal and the Washington Post." "With all the lawsuits over fake paintings and eBay scams, it's good to know that there's a trusted source to go to for authentic luxury merchandise...") and preferences ( such as USA, Europe or Dubai?).

The discourses about the perception of the different types of risk that we found in the literature were absent. The highest frequencies of discussion about pre- and aftersales service comments were found in luxury travel blogs.

We summarized our results and the attributed type of discourses in Table 1.

Table 1. Summary of the discourse results of luxury bloggers using Web 2.0 techniques

\begin{tabular}{|c|c|c|c|}
\hline Key-words & Connotations & $\begin{array}{l}\text { Type of } \\
\text { discourse }\end{array}$ & Frequencies \\
\hline $\begin{array}{l}\text { I,I,m,you, be, } \\
\text { like, would, your, } \\
\text { me, am, should, } \\
\text { traveler, drivers }\end{array}$ & $\begin{array}{l}\text { Society being } \\
\text { and desires }\end{array}$ & Social & 4298 \\
\hline $\begin{array}{l}\text { To, for, that, this } \\
\text { t, as, } 2\end{array}$ & $\begin{array}{l}\text { Watch, car, } \\
\text { travel as a } \\
\text { subject }\end{array}$ & Ideological & 2257 \\
\hline The, this, hours & For the watch & Relational & 1836 \\
\hline $\begin{array}{l}\text { Watch, it, } \\
\text { watches, one, 1, } \\
\text { its, them, clock, } \\
\text { car, cars, vehicle, } \\
\text { driving, drive, } \\
\text { road, automotive, } \\
\text { art, work, objects, } \\
\text { object, artwork, } \\
\text { things, ideas, } \\
\text { conceptual }\end{array}$ & $\begin{array}{l}\text { Watch, car, art } \\
\text { object, travel } \\
\text { itself and } \\
\text { subject }\end{array}$ & $\begin{array}{l}\text { Relational } \\
\text { Ideological }\end{array}$ & 2295 \\
\hline At, in from, there & $\begin{array}{l}\text { Place of } \\
\text { distribution } \\
\text { (selling points) }\end{array}$ & Functional & 1049 \\
\hline $\begin{array}{l}\text { My, have, may, } \\
\text { has, get, wearing, } \\
\text { got, wear, had, } \\
\text { own, getting, } \\
\text { mine, first, next, } \\
\text { used, take }\end{array}$ & $\begin{array}{l}\text { Property or } \\
\text { would like to } \\
\text { have one }\end{array}$ & Relational & 1696 \\
\hline $\begin{array}{l}\text { Omega, Rolex, } \\
\text { IWC, tag,heurer, } \\
\text { cartier, tank, } \\
\text { Paneira, piguet, } \\
\text { audemars, oak, } \\
\text { royal, pate, } \\
\text { hublot, breitling, } \\
\text { Mercedes, jaguar, } \\
\text { Chrysler, } \\
\text { Shermans Travel, } \\
\text { Skydini }\end{array}$ & $\begin{array}{l}\text { Name of the } \\
\text { brand (context } \\
\text { is unknown) }\end{array}$ & $\begin{array}{l}\text { Relational } \\
\text { Ideological } \\
\text { Social }\end{array}$ & 743 \\
\hline $\begin{array}{l}\text { Great, good, } \\
\text { very, love, well, } \\
\text { best, nice, } \\
\text { special, beautiful, } \\
\text { happy, favorite, } \\
\text { like, bad, best, } \\
\text { unique }\end{array}$ & $\begin{array}{l}\text { Emotions and } \\
\text { subject }\end{array}$ & $\begin{array}{l}\text { Relational } \\
\text { Ideological }\end{array}$ & 747 \\
\hline $\begin{array}{l}\text { Views, think, } \\
\text { view }\end{array}$ & $\begin{array}{l}\text { Opinions or } \\
\text { referring to } \\
\text { watch views, } \\
\text { subject }\end{array}$ & Ideological & 517 \\
\hline $\begin{array}{l}\text { About, new, } \\
\text { know, most, } \\
\text { actually, flash }\end{array}$ & Tendencies & $\begin{array}{l}\text { Relational } \\
\text { social }\end{array}$ & 415 \\
\hline $\begin{array}{l}\text { Looking, how, } \\
\text { who, where, } \\
\text { want, ask, tell, } \\
\text { interested, }\end{array}$ & $\begin{array}{l}\text { Research for } \\
\text { special } \\
\text { information - } \\
\text { communication }\end{array}$ & Functional & 450 \\
\hline
\end{tabular}




\begin{tabular}{|c|c|c|c|}
\hline $\begin{array}{l}\text { interest, need, } \\
\text { wanted }\end{array}$ & channel & & \\
\hline $\begin{array}{l}\text { More, much, } \\
\text { price, cheap, } \\
\text { expensive }\end{array}$ & Pricing & Functional & 239 \\
\hline $\begin{array}{l}\text { Time, ago, years, } \\
\text { old, year }\end{array}$ & Subject & $\begin{array}{l}\text { ideological } \\
\text { et historical }\end{array}$ & 238 \\
\hline $\begin{array}{l}\text { They, we, brand, } \\
\text { their, company }\end{array}$ & Brands & $\begin{array}{l}\text { Relational } \\
\text { Ideological } \\
\text { social }\end{array}$ & 354 \\
\hline $\begin{array}{l}\text { Gold, steel, } \\
\text { diamonds, } \\
\text { leather, diamond }\end{array}$ & Materials & Technical & 189 \\
\hline $\begin{array}{l}\text { Master, vintage, } \\
\text { collection, model, } \\
\text { classic, edition, } \\
\text { seamaster, } \\
\text { models, } \\
\text { submariner }\end{array}$ & $\begin{array}{l}\text { Model in } \\
\text { general, } \\
\text { Subject }\end{array}$ & $\begin{array}{l}\text { Relational } \\
\text { ideological }\end{array}$ & 166 \\
\hline $\begin{array}{l}\text { Dial, } \\
\text { chronograph, } \\
\text { chrono, long, } \\
\text { automatic, small, } \\
\text { tires, tire, flat, } \\
\text { back, feature, } \\
\text { engine, liter, fuel, } \\
\text { safety, high parts }\end{array}$ & $\begin{array}{l}\text { Technical } \\
\text { information }\end{array}$ & Technical & 320 \\
\hline $\begin{array}{l}\text { Black, white, } \\
\text { pink, yellow }\end{array}$ & Colors & $\begin{array}{l}\text { Relational } \\
\text { Social }\end{array}$ & 113 \\
\hline $\begin{array}{l}\text { First, original, } \\
\text { next, originally, } \\
\text { choice }\end{array}$ & $\begin{array}{l}\text { First, current, } \\
\text { original or next } \\
\text { watch }\end{array}$ & Relational & 113 \\
\hline $\begin{array}{l}\text { Strap, case, } \\
\text { bracelet }\end{array}$ & $\begin{array}{l}\text { Parts of the } \\
\text { watch }\end{array}$ & Technical & 86 \\
\hline Buy, bought & $\begin{array}{l}\text { Intention to } \\
\text { buy... or } \\
\text { already done }\end{array}$ & Functional & 59 \\
\hline Way, back & Delivery & Functional & 47 \\
\hline Diving, dive & $\begin{array}{l}\text { For what for... } \\
\text { (you should } \\
\text { wear this watch } \\
\text { for...) }\end{array}$ & Social & 40 \\
\hline Service, help & Service & Functional & 207 \\
\hline $\begin{array}{l}\text { Dubai, Jamaica, } \\
\text { bahia, } \\
\text { Miami,York, } \\
\text { America, } \\
\text { oriental, } \\
\text { mandarin, } \\
\text { Hudson, } \\
\text { American, world }\end{array}$ & $\begin{array}{l}\text { Distribution } \\
\text { place or better } \\
\text { price? } \\
\text { Examples of } \\
\text { destination }\end{array}$ & Functional & 170 \\
\hline Design & & $\begin{array}{l}\text { Functional } \\
\text { Relational }\end{array}$ & 16 \\
\hline
\end{tabular}

\section{Research and managerial implications}

\section{Further research implications}

Netnography as a marketing research tool was used for analyzing luxury blog comments but should be tested on a wider range in order to verify whether its use can be generalized and to find out its eventual limitations. Results of netnography methodology should be compared with more traditional research methods and confirmed as a valid research tool. Marketing practitioners are already using a method which is called "Hyperprofiling" [18] in the e-marketing sector.

The categorization based on the level of involvement of Netsurfers could be used on the content of the 23 selected blogs. The software we used to count frequencies should also be used to count the frequencies of the different user-names of Netsurfers. Then categories should be assessed as the best data sources.

We focused on the stated attitudes of luxury bloggers. But are they good indicators of the real consumption behaviors of either online or of traditional physical retailing customers?

\section{Implication for managers}

We focused on the behavior and attitude of the blogger as Netsurfers, which demonstrated clearly that the Web 2.0 techniques belong to their daily lives and that confirmed our research hypothesis, namely that luxury brands cannot ignore the Web 2.0 any longer as a communication and/or distribution channel. Luxury consumers who are using regularly Web 2.0 techniques cannot be longer ignored by luxury companies. They are experts in branding, are well informed in products that they are fond of, have bought various models or services, and are interested in buying more models or services in the future. The Internet is used as real information search tool for obtaining the latest news via other bloggers. They rarely talk about their physical shopping experiences.

Our outcomes about the attitudes and behaviors of Netsurfers allow considerations in integrating those aspects in designing future e-commerce platforms. As it is not possible by now to analyze attitude and behavior on official virtual shops of luxury product or service companies, our results aim at a better understanding of attitudes and behaviors in regard to existing distribution channels and designing new selling opportunities

\section{Conclusions}

This paper focuses on the Netnography methodology applied to the luxury sector. Results might be integrated into the design process of the online strategy of luxury goods companies. We found useful information about luxury consumers' attitudes and expectations. We illustrated how we may use Netnography as a research tool in order to collect data to enrich luxury marketing issues and integrate the data analysis results in a decision process when launching e-commerce solutions. 
Discourses of bloggers about whether customers either need or do not need to integrate at some moment a physical experience before ordering on the internet do not give a clear answer. Results show that the consumers are very concerned about everything which goes with the luxury product, meaning the service from the very beginning to after sales.

\section{References}

[1] Kozinets, R.V. I want to believe: A netnography of the Xfiles' subcultures of consumption, Advances in Consumer Research, 24: 470-475, 1997.

[2] Kozinets, R.V., and J. Handelman. Ensouling consumption: A netnography exploration of meaning of boycotting behavior, Advances in Consumer Research, 25: 475-480, 1998.

[3] Kozinets, R.V. On netnography: Initial reflections on consumer research investigations of cyberculture, Avances in Consumer Research, 25: 366-371, 1998.

[4] Konzinets, R.V. The field behind the screen: Using netnography for marketing research in online communities, Journal of Marekting Research, 39: 61-72, 2002.

[5] Nyeck, S., and E. Roux. www as a communication tool for luxury brands: compared perceptions of consumers and managers, Proceedings of the Second International Research Seminar on Marketing Communication and Consumer Behavior, La Londe Les Maures, 1997.

[6] Dall'Olmo Riley, F., and C. Lacroix. Luxury branding on the Internet: lost opportunity or impossibility?, Marketing Intelligence \& Planning, 21: 96-104, 2003.

[7] Lee, B.C.Y. Consumer attitude toward virtual stores and its correlates. Journal of Retailing and Consumer Services, 14: 182-191, 2007.

[8] Wang M.-S., Chen C.-C., Chang S.-C., and Y.-H. Yang. Effects of Online Shopping Attitudes, Subjective Norms and Control Beliefs on Online Shopping Intentions: A Test of the Theory of Planned Behavior. International Journal of Management, 24: 296-302, 2007.

[9] Metha R., and E. Sivadas. Direct Marketing on the Internet: An Empirical Assessment of Consumer Attitudes. Journal of Direct Marketing, 9: 22-32, 1995.

[10] Bergadaà, M., and M.J. Hebali. Les seniors utilisateurs d'Internet: typologie induite d'une recherche qualitative enligne. Research Seminar on Marketing communications and Consumer Behavior, La Londe les Maures, 2001.

[11] Weltevreden, J.W.J. Substitutions or complementarity? How the Internet changes city centre shopping. Journal of Retailing and Consumer Services, 14: 192-207, 2007.
[12] Turkle, S. Life on the screen-Identity in the Age of the Internet, Simon and Shuster, New York, 1995

[13] Knight, J. DVD, Video and Reaching Audiences. Experiments in Moving-Image Distribution, Convergence: The international Journal of Research into New Media Technologies, 13: 19-41, 2007.

[14] Miller, P. Monitoring the Blogosphere, Communication World, May-June: 33-36, 2006.

[15] Mc Kinnon. How blogs are affecting Media relations, 29 September 2007. www.infocomgroup.net/falkow/?p=79

[16] O'Reilly, T. 22 November 2007. http://www.oreilly.com/pub/a/oreilly/tim/news/2005/09/30/what -is-web-20.html,

[17] Parise, S., and P.J. Guinan. Marketing Using Web 2.0, Proceedings of the $41^{\text {st }}$ Hawaii International Conference on System Sciences; IEEE, 2008

[18] 2e Forum E-Marketing, 29-30 janvier 2008, Paris.

\section{About the Authors}

Magali Dubosson is the Managing Director of Haute Ecole de Gestion de Genève (Geneva School of Business Administration - HEG) and Services Marketing Professor. She is also part of the Institute for Service Innovation and Strategy Essec, Paris and IEEE member.

Jean-Philippe Trabichet is the Dean of the IT Department of Haute Ecole de Gestion de Genève (Geneva School of Business Administration - HEG) and Business Information System Professor. He is also in charge of the Institute of the Applied Technologies.

Alexandra Broillet is working as a research assistant at the Haute Ecole de Gestion de Genève (Geneva School of Busines Administration -HEG). She has got her master's degree from University of Geneva and is currently writing her Ph.D thesis. 